\title{
Education for Sustainable Development-The Case of Massive Open Online Courses
}

\author{
Agnieszka Hajdukiewicz ${ }^{\mathbb{D}}$ and Bożena Pera *⿻一𠃋 \\ Department of International Trade, Cracow University of Economics, 31-510 Kraków, Poland; \\ hajdukia@uek.krakow.pl \\ * Correspondence: perab@uek.krakow.pl
}

Received: 14 September 2020; Accepted: 11 October 2020; Published: 15 October 2020

check for updates

\begin{abstract}
Education for Sustainable Development (ESD) is a key instrument in transforming societies towards sustainable development, which can play a crucial role in the achievement of Agenda 2030 Sustainable Development Goals. The main purpose of this paper is to explore the current status and problems of implementation of Education for Sustainable Development by examining the sustainability-related knowledge content included in the higher education curriculum, with a special focus on the Massive Open Online Courses (MOOCs). We used both qualitative and quantitative data collection and analysis methods, including keyword analysis of selected MOOCs' syllabuses, to capture the nature of the studied phenomenon and enable assessment of the degree to which the sustainable development goals are integrated into the learning content. We found that most of 17 SDGs are reflected in the MOOCs learning content, but in case of some learning topics, such as "Zero hunger" and "Peace, Justice and Strong Institutions", a bigger effort should be made to include them more broadly in the curricula. The research results can support educators' efforts in identifying and incorporating challenging issues within the processes of curriculum development, indicating the need for a holistic and interdisciplinary approach, in which sustainability should be mainstreamed into all aspects of education.
\end{abstract}

Keywords: education for sustainable development; massive open online courses; MOOCs; sustainable development goals; course description

\section{Introduction}

Sustainable development is a priority policy issue for governments and one of the greatest challenges for societies. The role of education in achieving sustainability is crucial and unquestionable. People have to learn new skills, assimilate new values and attitudes to keep up with the transition to sustainability and be able to cope with such challenges as climate change, poverty reduction, biodiversity, social inequality or sustainable consumption [1-3].

Thus, education systems must define relevant learning objectives and learning contents, that empower learners to contribute to sustainable development, by turning them into sustainability change makers, who take informed decisions and act in a sustainable manner in a complex business environment.

The new 2030 Agenda for Sustainable Development of United Nations recognizes the importance of an appropriate education response in transformation towards sustainability. Education is explicitly formulated as a stand-alone goal, one of 17 Sustainable Development Goals (SDGs) in the agenda. Numerous education-related targets are also contained within other SDGs, since education can contribute to all the goals [1,4]. The transition to sustainability should be supported by Education for Sustainable Development (ESD) at different levels of education, from preschool to tertiary education until lifelong learning. New opportunities in this regard are created by the growing popularity of 
Massive Open Online Courses (MOOCs), which have captured a lot of public attention, offering many new teaching and learning solutions.

Whereas researchers often study sustainable development and underline the role of education in achieving sustainable development goals, we think that little research focuses on the problems of the inclusion of sustainable development goals to the education content, particularly within the framework of MOOC-based learning. In our opinion, there is a research gap concerning the problems of transition of sustainable development objectives into formal and non-formal educational practice.

The main purpose of this paper is to explore the current status and problems of implementation of Education for Sustainable Development by examining the sustainability-related knowledge content included in the higher education curriculum. Special focus will be placed on the MOOCs in the discipline of Economics and Finance.

In view of the identified research gap, we will try to answer the following research questions: (1) To what extent are sustainable development goals reflected in the learning content of MOOCs in the discipline of Economics and Finance? (2) Which of these goals are reflected the most in the curriculum?

This paper is organized as follows: first, the literature pertinent to the concept of education for sustainable development (ESD) and the role of MOOCs is summarized. Next, the study method is outlined to be followed by a presentation of the research findings. The paper concludes with a discussion of the outcomes, limitations and suggestions for further studies. The conclusion also contains some recommendations for educators to enable a wider recognition of sustainable development goals in MOOC-based education.

In order to answer the research questions, we applied mixed-methods approach. We used both qualitative and quantitative data collection and analysis methods, including the keyword analysis of selected MOOCs' course syllabuses, to capture the nature of the studied phenomenon and enable assessment of the degree to which the sustainable development goals are integrated into the learning content.

Based on comprehensive literature reviews, qualitative and quantitative analyses and authors' reflections, the study provides deeper insights into the problems of transition of sustainable learning into the curriculum. While, in this study, we focus on the MOOC course's content only, we acknowledge that the developments of the key competences needed for promoting sustainable developments are not limited to integrating certain content into course syllabuses, but require a shift towards active, participative and often experiential learning and teaching methods, at all levels of education. Therefore, we think that the further and broader research is needed to address the problem of creation of more action- and problem-oriented, learner-centered, interactive inter- and transdisciplinary learning, both formal and informal, aimed at enabling a more sustainable society.

\section{Literature Review}

\subsection{The Concept of Education for Sustainable Development (ESD)}

In the literature, education for sustainable development (ESD) is commonly viewed as an approach in education which allows knowledge, skills, attitudes and values to develop that support sustainable development [1-3]. Both sustainable development and education for sustainable development have been a part of global discourse over the past decades. One of the most popular and often-quoted definitions of the term "sustainable development" was introduced in 1987 by the World Commission on Environment and Development (Brundtland Commission). It the Brundtland Report, the term "sustainable development" is defined as "development that meets the needs of the present without compromising the ability of future generations to meet their own needs" [5]. According to the report, sustainable development arises from two key concepts: the concept of "needs", in particular the essential needs of the world's poor, and the idea of limitations imposed by the state of technology and social organization on the environment's ability to meet present and future needs. The Union of Conservation Scientists (IUCN), United Nations Environment Programme (UNEP) and World Wide 
Fund for Nature (WWF) [6] described sustainable development as "improving the quality of human life while living within the carrying capacity of supporting ecosystems". In 1994, the ICLEI (International Council for Local Environmental Initiatives) proposed to define SD as "development that delivers basic environmental, social and economic services to all residents of a community without threatening the viability of natural, built and social system upon which the delivery of those systems depends" [7]. In its evolution, the "three-pillar" concept of sustainable development has become widespread as a concept based on three interconnected dimensions or pillars of sustainability: economic, social, and environmental [8]. Complete sustainable development is achieved through a balance between all these pillars; however, the required condition is not easy to achieve. Some scholars add additional aspects or dimensions of SD-institutional, political, cultural or technical [9].

Education for Sustainable Development is a concept that has evolved in line with emerging sustainability issues [4]. The ESD started being institutionalized in 1992 with the international recognition of Agenda 21 and its specific chapter 36 acknowledging the importance of education for sustainable development at the UN Earth Summit in Rio de Janeiro [10]. In Article 36, the UN widened the concept of sustainable education from ecological education to the more comprehensive concept of education for sustainable development, claiming that "in order to support the process of sustainable development, a change of thinking and paradigm was needed, which would require an education strategy that has in mind to qualify societies to contribute to sustainable development" [11].

Reflecting the vivid discourse over sustainable development issues, the ESD has no single, uncontested definition and interpretation, and often terms such as Education for Sustainability (EfS) or Sustainability Education (SE) are used interchangeably. Some scholars distinguish between (1) education about sustainable development and (2) education for sustainable development. While the first may refer mainly to knowledge transfer about SD, transmitting facts about sustainability concepts without challenging existing assumptions, the second underlines the perception of a learning process, focusing more on a transformative approach to education [4]. This latter focus is also set in the new definition of ESD by United Nations Educational, Scientific and Cultural Organization (UNESCO) [1]: "ESD aims at developing competencies that empower individuals to reflect on their own actions, taking into account their current and future social, cultural, economic and environmental impacts, from a local and a global perspective. Individuals should also be empowered to act in complex situations in a sustainable manner, which may require them to strike out in new directions; and to participate in socio-political processes, moving their societies towards sustainable development" [12].

There are two distinct approaches to the ESD, directed to different learning outcomes: the empowerment perspective and the behavior modification perspective. Whereas the empowerment perspective focuses on enabling students to become independent critical thinkers, the behavior modification perspective strives to alter the learner's habits in line with more or less prescribed ideals $[2,13]$.

On 25 September 2015, the UN General Assembly announced the 2030 Agenda for Sustainable Development, following the arrangements of United Nations Conference on Sustainable Development (Rio+20) in Rio de Janeiro, Brazil in June 2012. The 2030 Agenda contains 17 Sustainable Development Goals (SDGs), which describe major current development challenges for humanity (see Table 1) [14].

With the adoption of the 2030 agenda education is embraced by the goal 4 (SDG 4), which aims to "ensure inclusive and equitable quality education and promote lifelong learning opportunities for all." Under Goal Four (SDG 4) there are seven specific targets. Target 4.7 is recognized as one of the most ambitious, challenging targets, which aims to, "By 2030, ensure that all learners acquire the knowledge and skills needed to promote sustainable development, including, among others, through Education for Sustainable Development and sustainable lifestyles, human rights, gender equality, promotion of a culture of peace and nonviolence, global citizenship and appreciation of cultural diversity and of culture's contribution to sustainable development" [14].

However, due to the interdependence of sustainability challenges across SDGs, a successful implementation of SDG 4 can influence the success of other goals [15]. All SDGs are interdependent. 
They can only be achieved if implemented together. In addition to a stand-alone goal on education, the 2030 Agenda also includes targets on education under several other SDGs, in particular those on health, economic growth and decent work, sustainable consumption and production and climate change. Thus, transformations of education in the perspective of the 2030 Agenda are related both to the implementation of SDG4, as well as education-related targets across the other SDGs (see Table 1).

Table 1. The 2030 Agenda Sustainable Development Goals (SDGs).

\begin{tabular}{|c|c|c|}
\hline Goal Number & $\begin{array}{l}\text { Goal Name and a Short } \\
\text { Description }\end{array}$ & $\begin{array}{l}\text { Keywords/Phrases Used in } \\
\text { Recommended Learning Topics }\end{array}$ \\
\hline SDG 1 & $\begin{array}{l}\text { "No poverty" —End poverty in all } \\
\text { its forms everywhere }\end{array}$ & $\begin{array}{c}\text { Poverty; social welfare, microfinance; } \\
\text { malnutrition; equal rights/access to } \\
\text { economic resources; development } \\
\text { cooperation; pro-poor development } \\
\text { strategies; gender-sensitive development } \\
\text { strategies. }\end{array}$ \\
\hline SDG 2 & $\begin{array}{l}\text { "Zero hunger"-End hunger, } \\
\text { achieve food security and } \\
\text { improved nutrition and promote } \\
\text { sustainable agriculture }\end{array}$ & $\begin{array}{l}\text { Hunger; malnutrition; functions of food; } \\
\text { food abundance, obesity; food waste; food } \\
\text { security; international trade with food; } \\
\text { subsidies in agriculture; GMOs; FAO; Slow } \\
\text { Food. }\end{array}$ \\
\hline SDG 3 & $\begin{array}{c}\text { Good Health and } \\
\text { Well-Being-Ensure healthy lives } \\
\text { and promote well-being for all at } \\
\text { all ages }\end{array}$ & $\begin{array}{l}\text { Promoting vaccines; healthy food; physical } \\
\text { activity; mental health; medical } \\
\text { consultation and education; health } \\
\text { programs and services; sexual and } \\
\text { reproductive health care service; family } \\
\text { planning; drug prevention; reduction of } \\
\text { pollution and contamination; HIV } \\
\text { prevention programs; road traffic accidents; } \\
\text { overweight and obesity. }\end{array}$ \\
\hline SDG 4 & $\begin{array}{l}\text { "Quality Education"_-Ensure } \\
\text { inclusive and equitable quality } \\
\text { education and promote lifelong } \\
\text { learning opportunities for all }\end{array}$ & $\begin{array}{l}\text { The Education } 2030 \text { agenda; lifelong } \\
\text { learning; diversity and inclusive education; } \\
\text { public financing of education; sustainability } \\
\text { skills and competencies; the use of ICT in } \\
\text { education; ESD; youth empowerment. }\end{array}$ \\
\hline SDG 5 & $\begin{array}{c}\text { Gender Equality-Achieve gender } \\
\text { equality and empower all women } \\
\text { and girls }\end{array}$ & $\begin{array}{l}\text { Gender inequality; gender discrimination; } \\
\text { gender equality; pay disparity; sexual and } \\
\text { reproductive health and rights; childcare; } \\
\text { women financial (in) dependence. }\end{array}$ \\
\hline SDG 6 & $\begin{array}{l}\text { Clean Water and } \\
\text { Sanitation-Ensure availability } \\
\text { and sustainable management of } \\
\text { water and sanitation for all }\end{array}$ & $\begin{array}{l}\text { Global water cycle; water distribution; } \\
\text { access to safe drinking water; water quality; } \\
\text { water sanitation; water security; water } \\
\text { scarcity; water use efficiency; wastewater } \\
\text { treatment; water-related programs; water } \\
\text { resources management }\end{array}$ \\
\hline SDG 7 & $\begin{array}{l}\text { Affordable and Clean } \\
\text { Energy-Ensure access to } \\
\text { affordable, reliable, sustainable } \\
\text { and clean energy for all }\end{array}$ & $\begin{array}{l}\text { Renewable energies; solar energy; wind } \\
\text { energy; water energy; geothermal energy; } \\
\text { energy efficiency; energy self-sufficiency; } \\
\text { LESCOs; solar farms; dam projects; low } \\
\text { carbon energy solutions; reduction of fossil } \\
\text { fuels use; environmental impact of energy; } \\
\text { climate change }\end{array}$ \\
\hline
\end{tabular}


Table 1. Cont.

\begin{tabular}{|c|c|c|}
\hline Goal Number & $\begin{array}{l}\text { Goal Name and a Short } \\
\text { Description }\end{array}$ & $\begin{array}{l}\text { Keywords/Phrases Used in } \\
\text { Recommended Learning Topics }\end{array}$ \\
\hline SDG 8 & $\begin{array}{l}\text { Decent Work and Economic } \\
\text { Growth-Promote sustained, } \\
\text { inclusive and sustainable } \\
\text { economic growth, full and } \\
\text { productive employment and } \\
\text { decent work for all }\end{array}$ & $\begin{array}{l}\text { Models and indicators of economic growth; } \\
\text { steady-state economies; common-welfare } \\
\text { economies; de-growth; subsistence } \\
\text { economies; investment;; credits; interests; } \\
\text { banks; speculations on the stock exchange; } \\
\text { inflation; labor force; migration; inequalities } \\
\text { in the labor market; labor rights; forced } \\
\text { labor; slavery and human trafficking; } \\
\text { sustainable entrepreneurship; (social) } \\
\text { innovation; sustainable new technologies; } \\
\text { sustainable local economies }\end{array}$ \\
\hline SDG 9 & $\begin{array}{c}\text { Industry, Innovation and } \\
\text { Infrastructure-Build resilient } \\
\text { infrastructure, promote inclusive } \\
\text { and sustainable industrialization } \\
\text { and foster innovation }\end{array}$ & $\begin{array}{l}\text { Sustainable information and } \\
\text { communication technology (ICT); quality } \\
\text { infrastructure; inclusive and sustainable } \\
\text { innovation and industrialization; } \\
\text { sustainable infrastructure; national grids; } \\
\text { feed-in tariffs; expanding sustainable } \\
\text { renewable sources; conflicts over energy; } \\
\text { sustainable Internet; green chat groups; the } \\
\text { ecological footprint of search-engine } \\
\text { servers; sustainable transport infrastructure }\end{array}$ \\
\hline SDG 10 & $\begin{array}{c}\text { Reduced Inequalities-Reduce } \\
\text { inequality within and among } \\
\text { countries }\end{array}$ & $\begin{array}{l}\text { Social, economic and political inequalities; } \\
\text { inequality measurements; social protection } \\
\text { policies; } \\
\text { global trade systems and regulations; labor } \\
\text { standards; international development aid; } \\
\text { migration }\end{array}$ \\
\hline SDG 11 & $\begin{array}{l}\text { Sustainable Cities and } \\
\text { Communities-Make cities and } \\
\text { human settlements inclusive, safe, } \\
\text { resilient and sustainable }\end{array}$ & $\begin{array}{l}\text { Sustainable energy; residential energy use, } \\
\text { renewable energies, community energy } \\
\text { schemes; Sustainable food; organic } \\
\text { agriculture and permaculture, community } \\
\text { supported agriculture, foodshed, food } \\
\text { processing, dietary choices and habits; } \\
\text { Urban ecology; waste management; } \\
\text { recycling; alternative communities, healthy } \\
\text { communities, inclusive communities, } \\
\text { ecovillages, transition towns; water cycle; } \\
\text { sustainable urban drainage; } \\
\text { disaster preparedness and resilience }\end{array}$ \\
\hline SDG 12 & $\begin{array}{l}\text { Responsible Consumption and } \\
\text { Production-Ensure sustainable } \\
\text { consumption and production } \\
\text { patterns }\end{array}$ & $\begin{array}{l}\text { Energy production and consumption; food } \\
\text { production and consumption; sustainable } \\
\text { lifestyles; sustainable production and } \\
\text { consumption; sustainable products labelling } \\
\text { systems and certificates; green economy; } \\
\text { cradle-to-cradle; circular economy; green } \\
\text { growth, de-growth; tourism,; waste } \\
\text { generation and management }\end{array}$ \\
\hline SDG 13 & $\begin{array}{l}\text { "Climate Action"-Take urgent } \\
\text { action to combat climate change } \\
\text { and its impacts }\end{array}$ & $\begin{array}{l}\text { Greenhouse gas emissions; climate } \\
\text { change-related hazards; institutions } \\
\text { addressing issues of climate change; policy } \\
\text { strategies to protect the climate; the global } \\
\text { warming; impacts on big eco-systems and } \\
\text { biodiversity }\end{array}$ \\
\hline SDG 14 & $\begin{array}{l}\text { "Life below Water"-Conserve } \\
\text { and sustainably use the oceans, } \\
\text { seas and marine resources for } \\
\text { sustainable development }\end{array}$ & $\begin{array}{l}\text { Water cycle; sustainable marine energy; } \\
\text { marine resources; marine ecology; } \\
\text { overfishing, fishing quotas; see level rise; } \\
\text { oceans and international law; ocean } \\
\text { pollutants; cultural ecosystem of the sea. }\end{array}$ \\
\hline
\end{tabular}


Table 1. Cont.

\begin{tabular}{|c|c|c|}
\hline Goal Number & $\begin{array}{l}\text { Goal Name and a Short } \\
\text { Description }\end{array}$ & $\begin{array}{l}\text { Keywords/Phrases Used in } \\
\text { Recommended Learning Topics }\end{array}$ \\
\hline SDG 15 & $\begin{array}{l}\text { Life on Land-Protect, restore and } \\
\text { promote sustainable use of } \\
\text { terrestrial ecosystems, sustainably } \\
\text { manage forests, combat } \\
\text { desertification, and halt and } \\
\text { reverse land degradation and halt } \\
\text { biodiversity loss }\end{array}$ & $\begin{array}{l}\text { Ecology; specific ecosystems; threats to } \\
\text { biodiversity; desertification, deforestation; } \\
\text { ecosystem services; genetics; genetic ethics }\end{array}$ \\
\hline SDG 16 & $\begin{array}{l}\text { Peace, Justice and Strong } \\
\text { Institutions-Promote peaceful } \\
\text { and inclusive societies for } \\
\text { sustainable development, provide } \\
\text { access to justice for all and build } \\
\text { effective, accountable and } \\
\text { inclusive institutions at all levels }\end{array}$ & $\begin{array}{c}\text { Crime and Punishment; Corruption; } \\
\text { corruption measurements; Climate Justice; } \\
\text { Trade Justice; The illegal weapons trade; } \\
\text { Drug trade; Child labour; The international } \\
\text { criminal court }\end{array}$ \\
\hline SDG 17 & $\begin{array}{l}\text { "Partnerships for the } \\
\text { Goals"-Strengthen the means of } \\
\text { implementation and revitalize the } \\
\text { global partnership for sustainable } \\
\text { development }\end{array}$ & $\begin{array}{l}\text { Global governance and markets promoting } \\
\text { sustainable development; development } \\
\text { cooperation; development assistance; } \\
\text { financial resources for developing countries; } \\
\text { sustainable development measurements }\end{array}$ \\
\hline
\end{tabular}

The importance of education for achieving the goals of the 2030 Agenda as well as the strong interdependencies across the 17 SDGs are acknowledged by Sachs et al. [16] in the Six Transformations approach to achieve the Sustainable Development Goals. The scholars claim that the transformations require fundamental changes in norms, belief systems and cognitive heuristics. Since such changes cannot be driven solely by governments and arise instead from dialogues and learning processes between stakeholders, they should be supported by transdisciplinary research and education.

ESD is holistic and transformational education that addresses learning content and outcomes, pedagogy and the learning environment. It represents a problem- and action-oriented, learner-centered, inter- and transdisciplinary approach to learning [1]. ESD aims to provide equitable opportunities to education in a lifelong learning perspective. It includes a strong commitment to ensuring inclusion, equity and gender equality. Moreover, it focuses on effective and relevant learning leading to the acquisition of relevant knowledge, skills and competencies, which are needed for promoting sustainable development [17].

To facilitate a change of the education system, governments need to design effective policies ensuring that education systems are adequate to sustainability challenges. This includes, among others, integrating ESD into curricula and national quality standards, and developing relevant indicator frameworks that establish standards for sustainability-related intended learning outcomes [1]. ESD content should not be considered as an added element to the existing curriculum, but instead sustainability should be mainstreamed into the all aspects of education (such as the learning content, campus operations, organizational culture, student participation, leadership and management, research, etc.). Crucial issues for the successful implementation of policies promoting ESD include among others the following aspects [1]:

- ESD has to be integrated coherently across relevant sectorial or subsectorial policies; in particular, full policy coherence between the education sector and the sustainable development sector has to be ensured;

- Political and socio-cultural realities and environmental as well as ecological challenges, which determine ESD, differ between countries; thus, locally and nationally relevant interpretations of ESD and related forms of education should be developed; 
- Coordinating bodies and mechanisms should be created at different levels of the education system, along with setting targets for ESD and with supporting non-governmental organizations (NGOs) in their activities related to education.

\subsection{The Role of MOOCs in the Education for Sustainable Development}

A MOOC is a model for delivering learning content online to any person who wants to take a course, with no limit on attendance [18]. MOOCs, as currently designed, are learning formats that can combine traditional forms of learning with informal learning approaches. Most of MOOC platforms (such as, e.g., Coursera, OpenupED, Udacity or edX), created at the beginning of the 2010s, offer education in a so-called freemium model, which means that basic education modules are free but students must pay for further education as well as certificates or diplomas. MOOCs address two of the three challenges facing postsecondary education: access and cost. According to [19], MOOC-based degree programs would not only democratize education, but their scalability would help end the unsustainable trajectory of tuition. They are an effective remedy to the "cost disease" plaguing higher education and a viable solution to the problem of providing global access to educational credentials. This format has helped to open the previously closed system of higher education, and has thus also enabled universities and colleges to reach more students and learners than ever before [11].

Over the years, MOOCs have been integrated and transformed into several learning variations. By integrating formal traditional courses with informal learning experience, MOOCs have been expanding the position as a learning format to provide students with diverse learning experiences delivered through blended learning modalities [20].

According to Islam, Akter and Knezevic [21], the (initial) philosophy of MOOCs was to open up quality education to a wider audience. As such, MOOCs can be an important tool to achieve Goal 4 of the 2010 Agenda for Sustainable Development ("Ensure inclusive and equitable quality education and promote lifelong learning opportunities for all"). MOOCs can facilitate as well as strengthen the education to a significant extent. The advantages of MOOCs, from the perspective of their (potential) relationship with the ESD, include among others the following aspects:

- MOOCs are nowadays used as a means of making education more accessible to the people, regardless of gender, race, religion or geographical locality;

- MOOCs can make access to education easier for students with certain disabilities, such as motor impairment. However, their format may be inaccessible to students who have vision or hearing impairment, so MOOCs' designers should break this important barriers to guarantee their accessibility so they do not discriminate any person [22];

- MOOCs can be designed as an alternative way for providing scope for skill-based education at a minimum cost, offering need-based training and equipping learners with need-based skills, which are necessary for maintaining a decent standard of living [23];

- With the developing of computer and Internet technologies, MOOCs could be an effective tool for transferring knowledge and it has a potential to overtake the traditional teaching method; the technology provides a higher interaction and collaboration level between instructors or lectures and peers than traditional environment for learning [21];

- It also encourages people to share their knowledge and innovative thoughts by using various means of MOOCs in a wider context;

- One of the major advantage of MOOCs lies in its flexibility. The curriculum can be repeated until it is understood by the students, who can gain multiple learning ways depending on their needs;

- Students can choose between many variants of online courses (e.g., connectivist MOOCs-cMOOCs, and commercial xMOOCs); in case of cMOOCs content, is decided upon and contributed by the participants themselves to a big extent, whereas xMOOCs are based in a traditional university teaching [22];

- MOOCs are an instrument of informal and lifelong learning [24]. 
The results of the study by Coursera [25] support the view that MOOCs can contribute to the goals of ESD as formulated in Agenda 21: "Countries could support university and other tertiary activities and networks for environmental and development education. Crossdisciplinary courses could be made available to all students and provide an opportunity for those who are less advantaged and have limited access to education". Over the last few years, more than one million people have completed courses from Coursera alone, and more than 100,000 people have certified completion from Harvard- and MIT-based MOOCs. Under a decade, MOOCs have reached in total 110 million users, a big percentage of them coming from developing countries [11].

However, the question remains whether this type of innovative education format is nowadays merely a success in terms of student numbers or whether it actually contributes a valid and high-quality learning experience that will support achieving all sustainable development goals listed in the 2030 Agenda? Taking into account the existing research gap, in our study we will try to address the more specific research question: To what extent are sustainable development goals reflected in the contemporary learning content of MOOCs?

\section{Methodology}

The aim of this paper is to investigate and assess the present status and problems of implementation of Education for Sustainable Development by examining the sustainability-related knowledge content included in the higher education curricula. We focus on MOOCs, because this phenomenon of open learning has grown tremendously since the first online course was provided in 2008 [26,27]. Educational and learning platforms offer courses in various scientific disciplines, but our study targets MOOCs in economics and finance.

In our paper, we use both quantitative and qualitative methods of research. The studies were carried out following the diagram provided in Figure 1.

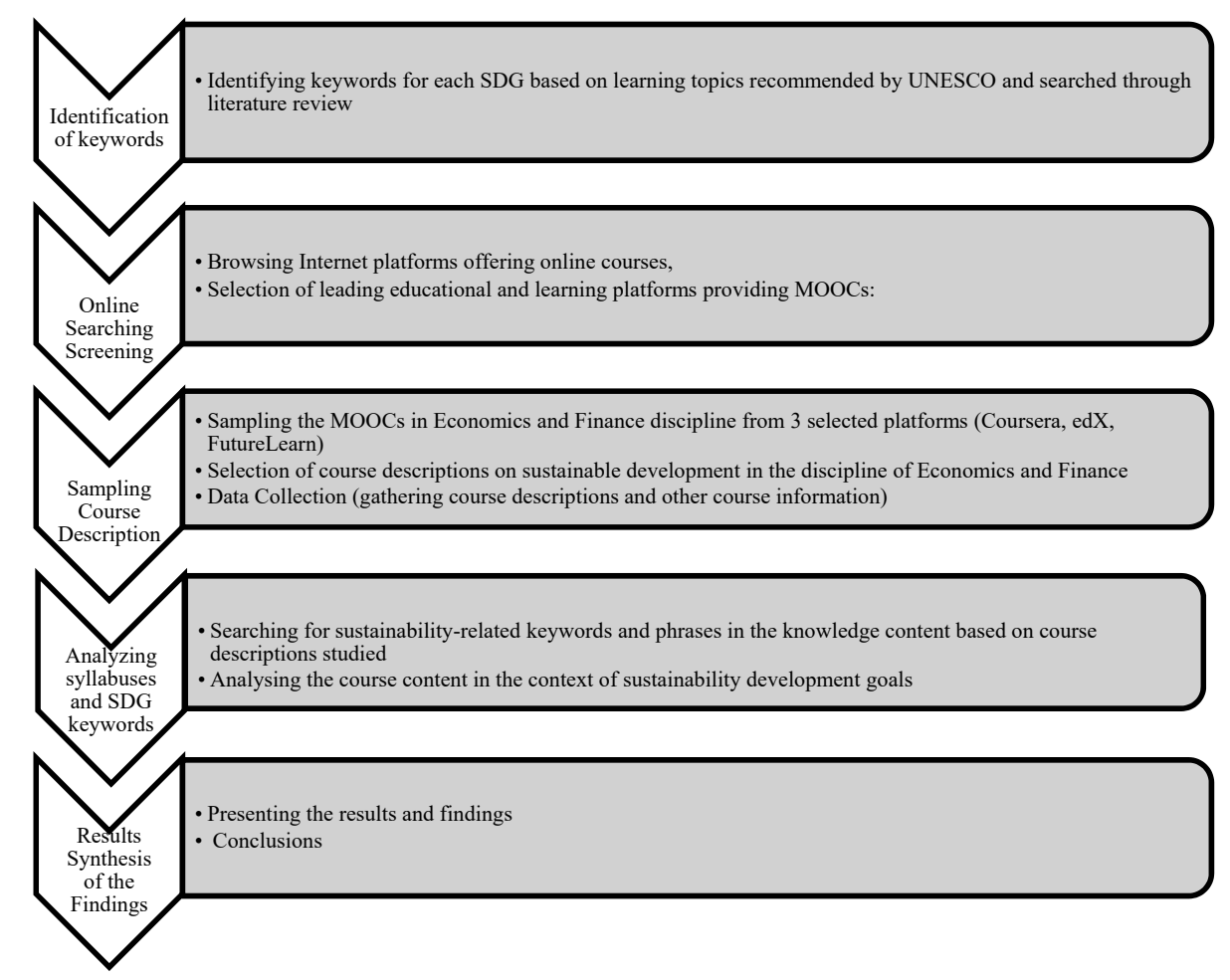

Figure 1. Research conceptualization. Source: own elaborations.

First, in the initial phase of the research, focusing on UNESCO materials and literature review, keywords for each sustainable development goal were developed (Table 1). We identified the core keywords based on the suggested learning topics by UNESCO included in the guide entitled 
"Education for Sustainable Development Goals. Learning Objectives" [1], supplemented with some indications resulting from the conducted literature review. The study was limited to massive open online courses in economics and finance field, being one domain of tripartite model of sustainability $[8,28,29]$.

Secondly, considering the number of courses, from among 44 educational and learning platforms providing MOOCs, we have selected Coursera, edX and FutureLearn that offer the highest number of courses [30]. Coursera and edX platforms were founded in 2012, the first by two Stanford Computer Science professors [31], and the latter by Harvard University and MIT [32]. FutureLearn platform launched the first course in 2013 and is owned by The Open University [33]. The partners of these educational and learning platforms are the leading universities, international organizations, industry-leading companies from around the world. A total of 1959 MOOCs assigned to the economics and finance were collected in the screening process. We followed the browser tool provided by each educational and learning platform. Our research mainly targeted the implementation of sustainable development goals into the courses offered on three platforms taken together; however, we are aware of the existing variation among educational and learning platforms. Differences between various educational platforms are described by a number of authors [20,34-36].

Thirdly, we used systematic sampling, trying to choose courses evenly distributed. We assumed to select every tenth course on each of the platform studied and skipped those courses that were too loosely related to the discipline of economics and finance.

Then, course description was assigned to each course selected. Bearing in mind the next stage of the research, we used additional inclusion criteria: courses should be delivered in English and the description of learning content and goals must be provided in sufficient detail. After screening, the sample of 123 MOOCs meeting the inclusion criteria were identified as the final sample. The second group of MOOCs to which we refer in our study are online courses in sustainable development assigned to economics and finance. We used keywords "sustainable economics" to identify this group of courses. In case of two platforms, with the high number of courses, we applied systematic sampling again, and selected every fourth course in accordance with the predefined criteria. For the third platform selected, the total number of courses on sustainable economics was limited to a few courses (about $5 \%$ for the most represented platform) and we decided to include all of the courses in the further analysis. A total of $58 \mathrm{MOOC}$ samples were selected from all online courses in economics and finance. The data collection process was conducted from 24 July to 7 August 2020.

We used MAXQDA as a content analysis and the text-mining tool to identify keywords assigned to specific sustainable development goals in the syllabuses of the selected courses. We searched one by one for the keywords presented in Table 1 and, if they occurred in course description, we assigned them to a specific goal. Our content analysis of the collected courses referred both to the frequency of keywords (quantitative approach) and meaning of the words (qualitative approach). Moreover, analysis of both course samples was carried out by using descriptive statistics measures. The mixed methods of research applied in the study made it possible to obtain the results presented below.

\section{Results and Discussion}

The presentation of the outcomes will be supported by more in-depth description and analysis of the selected educational and learning platforms and groups of courses.

In our research, we will focus on the randomly selected courses and study the content of their syllabuses. Therefore, the results of the quantitative analysis of the identified courses in economics and finance and those related to sustainable development are presented in Table 2.

Coursera is the platform that offers the largest number of MOOCs among selected educational and learning platforms. Moreover, almost every third course provided on this platform, is assigned to the economics and finance discipline. In the case of the second platform-edX, only $10 \%$ of incorporated courses are courses in the scope of economics and finance. Total number of MOOCs provided by FutureLearn is almost seven times lower compared to Coursera, but courses classified as economics and finance courses have a similar share in total number of courses. Then, the role of sustainable 
economics courses offered by the selected platforms was considered. Courses enabling the acquisition of knowledge and skills on sustainable development goals were most frequently delivered on the edX platform. One in five courses assigned to field of economics and finance has referred to sustainable development issues. In the case of Coursera platform courses, sustainability represented only about $9 \%$ of total economic courses. The least number of these courses could be found on the FutureLearn platform. They represented only 3.3\% of the economic courses. Thus, further research was limited to 123 sampled MOOCs assigned to economics and finance and 58 courses assigned to sustainable economics (Table 2).

Table 2. Number of courses in the field of economics and finance and sampled courses provided by three leading educational and learning platforms (as of August 7, 2020).

\begin{tabular}{cccccc}
\hline \multirow{2}{*}{$\begin{array}{c}\text { Educational } \\
\text { and Learning } \\
\text { Platform }\end{array}$} & $\begin{array}{c}\text { Total } \\
\text { Number of } \\
\text { MOOCs }\end{array}$ & \multicolumn{2}{c}{$\begin{array}{c}\text { Courses in Economics and } \\
\text { Finance }\end{array}$} & $\begin{array}{c}\text { Courses in Sustainable } \\
\text { Economics (Belonging to } \\
\text { Discipline of Economics and } \\
\text { Finance) }\end{array}$ \\
\cline { 3 - 6 } & & Total Number & $\begin{array}{c}\text { Sample of } \\
\text { Courses }\end{array}$ & Total Number & $\begin{array}{c}\text { Sample of } \\
\text { Courses }\end{array}$ \\
\hline Coursera & 4671 & 1474 & 68 & 132 & 38 \\
edX & 3070 & 305 & 33 & 59 & 14 \\
FutureLearn & 617 & 180 & 22 & 6 & 6 \\
\hline
\end{tabular}

While two of the selected educational platforms were established in the US, all three platforms offered a number courses in economics and finance provided by US universities. UK universities offered much lower number of MOOCs than US institutions, but their offer was also significant as compared to the other countries in this group. MOOCs were also offered by universities located in the Netherlands, Australia and India on all three educational platforms. A total of 14 courses hosted on two educational platforms, were provided by universities from six countries. Most of these MOOCs were offered by universities from Switzerland, Hong Kong and Spain. There were 11 courses provided by universities from EU countries and two from Russia on one platform. One course-regarded as International—has been delivered by universities from Belgium, Denmark, Greece and the Netherlands in cooperation with a EU company. Educational institutions from countries outside Europe provided only two MOOCs in economics and finance on one platform only (Table 3).

In the second group of MOOCs, dedicated to sustainable economics, only courses designed by entities regarded as International have been offered on all three platforms. There were delivered by International Monetary Fund, Sustainable Development Academy and the Red Cross and Red Crescent Organization, among others. A number of MOOCs developed by US universities were provided on two platforms. In addition, Dutch universities delivered several courses in sustainable economics. Universities from EU countries were the most represented among MOOCs assigned to one educational platform. They provided a total of 13 courses on sustainable economics. In addition, two other universities from European countries outside the EU—one from the United Kingdom and one from Russia-also offered MOOCs, one course each. Moreover, universities from Australia, Hong Kong, India and Taiwan also provided courses on sustainable economics (Table 3).

Considering access to learning, it is also noteworthy that MOOCs offer the wide range of courses at different levels of study. Therefore, we have also examined the prerequisites for learners who would like to enroll in courses, which allowed courses to be categorized into four groups: introductory, intermediate level, advanced level and mixed courses. The courses at the beginner level dominated in both groups of MOOCs in economics and finance and in sustainable economics (about $45 \%$ and $35 \%$, respectively). The number of MOOCs requiring basic knowledge, skills and social competencies before the beginning of the study were about 9 p.p. higher in case of learning offerings in sustainable economics compared to courses in economics and finance. Therefore, the courses in sustainable 
economics seem to require on average more specific knowledge, skills and competences than the courses in economics and finance. The lowest share in total number of courses was recorded for advanced level courses, both in economics and finance (about $7 \%$ ) and in sustainable economics (about 6\%). An attractive alternative seems to be mixed courses, which enable all potential interested students, regardless of the initial level of advancement of knowledge, to enroll in courses, study and exchange learning experience. This group of courses accounted for approximately $29 \%$ of all courses offered in economics and finance and about $31 \%$ of courses in sustainable economics (Figure 2). Offering a variety of MOOCs at different levels enables a student's individual learning needs to be matched with relevant learning experiences, at the same time making education more accessible, which is in line with the vision of education for sustainable development.

Table 3. Distribution of Massive Open Online Courses (MOOCs) by countries of origin of universities or educational institutions offering courses on selected platforms.

\begin{tabular}{|c|c|c|}
\hline $\begin{array}{c}\text { Courses/Educational } \\
\text { Platforms }\end{array}$ & $\begin{array}{l}\text { MOOCs in Economics and } \\
\text { Finance * }\end{array}$ & $\begin{array}{l}\text { MOOCs in Sustainable } \\
\text { Economics * }\end{array}$ \\
\hline $\begin{array}{l}\text { MOOCs offered on all } 3 \\
\text { educational platforms }\end{array}$ & $\begin{array}{l}\text { The United States (59), The United } \\
\text { Kingdom (17), Netherlands (7), } \\
\text { Australia (6), India (3), }\end{array}$ & International (9) \\
\hline $\begin{array}{l}\text { MOOCs offered on } 2 \\
\text { educational platforms only }\end{array}$ & $\begin{array}{l}\text { Switzerland (4), Hong Kong (3), } \\
\text { Spain (3), South Africa (2), South } \\
\text { Korea (2), }\end{array}$ & $\begin{array}{l}\text { The United States (18), The } \\
\text { Netherlands (7), Switzerland (3), } \\
\text { South Africa (2), }\end{array}$ \\
\hline $\begin{array}{c}\text { MOOCs offered on } 1 \\
\text { educational platform only }\end{array}$ & $\begin{array}{c}\text { France (3), Denmark (2), Germany } \\
\text { (2), Italy (2), Russia (2), China (1), } \\
\text { Saudi Arabia (1), Sweden (1), } \\
\text { International (1), }\end{array}$ & $\begin{array}{c}\text { Denmark (3), France (3), Italy (3), } \\
\text { Australia (1), Finland (1), Germany } \\
\text { (1), Hong Kong (1), India (1), } \\
\text { Russia (1), Spain (1), Sweden (1), } \\
\text { Taiwan (1), The United Kingdom } \\
\text { (1). }\end{array}$ \\
\hline
\end{tabular}

* The number of courses is shown in brackets. Source: Own elaborations.

Sustainable development goals are reflected in most courses in all of the platforms, but not to the same degree (Figure 3).

Coursera was the platform with the highest share of sustainability development-related content incorporated into courses (about $42 \%$ of all references for economics and finance courses and $68 \%$ of coded phrases for economics sustainable courses). Nearly $34 \%$ of the keywords in the courses on economics and finance referred to sustainability on the edX platform. However, a much smaller share of references was recorded in the courses on sustainable economics ( $24 \%$ of total number of references in the mentioned field). In case of FutureLearn, the references for courses in the field of economics and finance accounted for $24 \%$ of total number of assigned keywords and, respectively, only $8 \%$ for courses on sustainable economics. The total number of identified keywords referring to sustainable development was about one-third higher in the case of sustainable economics courses as compared to economics and finance group (Figure 3). The detailed breakdown of the results for all of the three platforms taken together was presented in Table 4.

On the basis of descriptive statistics, it can be noticed that the distribution of keywords among the SDGs in each studied set of courses is different. The obtained results reveal that distribution of the keywords is skewed positively for both course sets. It means that a large number of keyword references is assigned to several SDGs in both groups. In the case of four SDGs less than 24 references were noted for selected courses in economics and finance. Meanwhile, the number of references was below 28 of coded terms in case of least frequently addressed goals for courses in sustainable economics. Moreover, in both bundles of courses, only four SDG recorded more than 61 references in economics and finance courses and 83 references, respectively, in sustainable economics. In the case of economics and finance courses, more than 44 references to keywords in half of the targets were observed for each of them. However, for the group of courses in sustainable economics, it was one reference less than in 
the previous group. The related keywords represented more than $80 \%$ of all coded phrases in both cases. However, in the group of courses addressing sustainable development, the concentration of references for leading objectives was higher $(81.13 \%$ and $85.59 \%$, respectively).

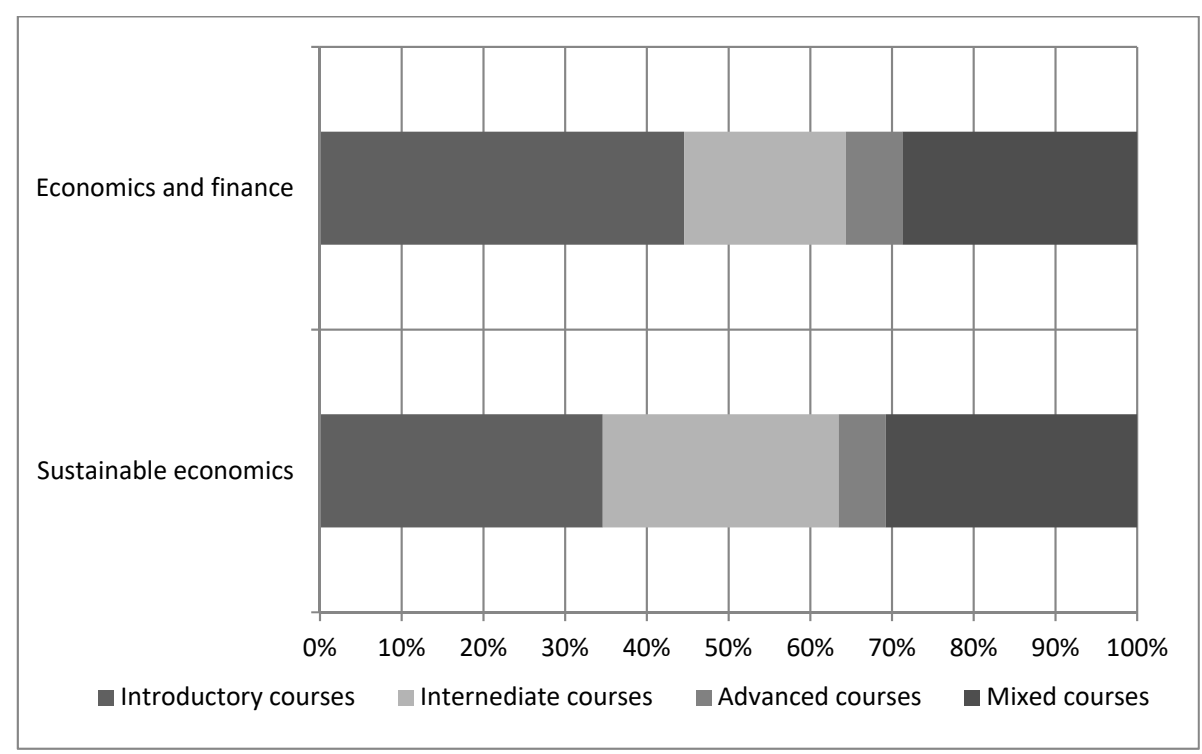

Figure 2. Structure of MOOCs by level of study (in \% of the total number of courses). Source: own elaboration.

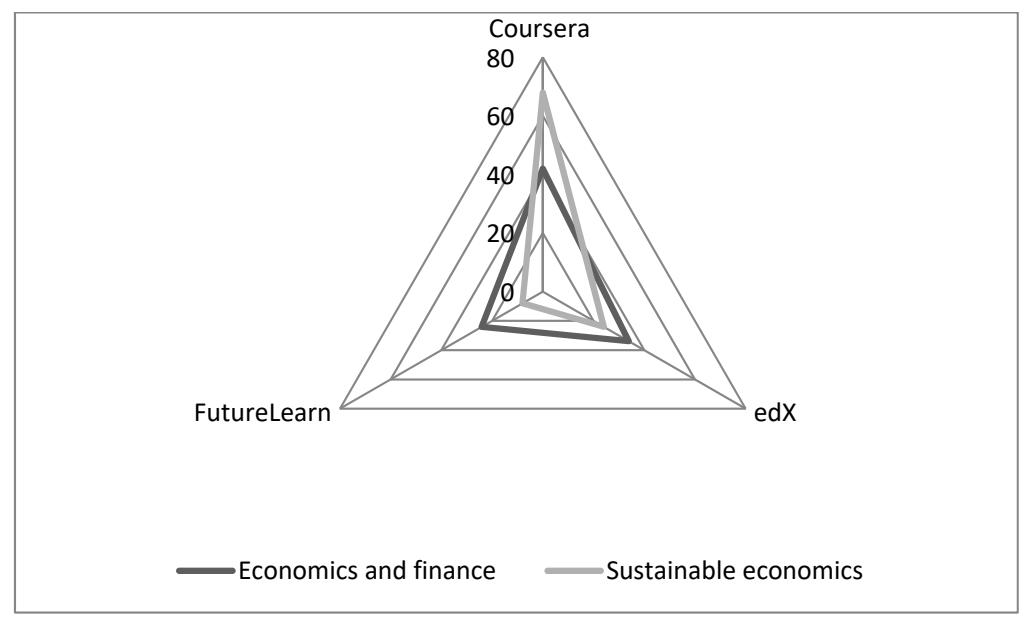

Figure 3. References to the SDG-related issues by group of courses and platform (in \% of total number of references). Source: own elaboration.

The keywords assigned to sustainable development goal 8. (SDG 8) entitled "Descent work and economic growth" dominated in the learning outcomes and knowledge contents of the studied courses in economics and finance. Every third keyword was related to this specific goal (33.96\% of all the coded). Relatively high scores recorded in the sampled courses related to industry, innovation and infrastructure issues (SDG 9) and health and well-being issues (SDG 3). In turn, "Zero hunger" (SDG 2) and "Peace, Justice and Strong Institutions" (SDG 16) were least integrated into the MOOCs content in economics and finance. The identified keywords in the courses belonging to the group fully focused on sustainable economic issues were mainly attributed to SDG 8, followed by keywords referring to quality education (SDG 4) and sustainable cities and communities (SDG 11). There were relatively few references in this group of courses to the goals: "Life below Water" (SDG 14), "Peace, Justice and Strong Institutions" (SDG 16) and "Clean Water and Sanitation" (SDG 6). Relatively a large number 
of references was related to "Industry, Innovation and Infrastructure" (SDG 9) and "Affordable and Clean Energy" (SDG 7) in both sets of courses (Table 4).

Table 4. Frequency of occurrence of SDG-related keywords in the sampled courses in economics and finance and in sustainable economics.

\begin{tabular}{|c|c|c|c|c|}
\hline \multirow[t]{2}{*}{ SDG } & \multicolumn{2}{|c|}{$\begin{array}{c}\text { Courses in Economics and } \\
\text { Finance }\end{array}$} & \multicolumn{2}{|c|}{$\begin{array}{c}\text { Courses in Sustainable } \\
\text { Economics }\end{array}$} \\
\hline & Total & Coded (in \%) & Total & Coded (in \%) \\
\hline SDG 1 & 45 & 4.72 & 34 & 2.36 \\
\hline SDG 2 & 1 & 0.10 & 77 & 5.34 \\
\hline SDG 3 & 85 & 8.91 & 31 & 2.15 \\
\hline SDG 4 & 61 & 6.39 & 206 & 14.29 \\
\hline SDG 5 & 44 & 4.61 & 12 & 0.83 \\
\hline SDG 6 & 10 & 1.05 & 10 & 0.69 \\
\hline SDG 7 & 62 & 6.50 & 81 & 5.62 \\
\hline SDG 8 & 324 & 33.96 & 463 & 32.11 \\
\hline SDG 9 & 96 & 10.06 & 114 & 7.91 \\
\hline SDG 10 & 34 & 3.56 & 28 & 1.94 \\
\hline SDG 11 & 28 & 2.94 & 146 & 10.12 \\
\hline SDG 12 & 53 & 5.56 & 43 & 2.98 \\
\hline SDG 13 & 48 & 5.03 & 64 & 4.44 \\
\hline SDG 14 & 4 & 0.42 & 1 & 0.07 \\
\hline SDG 15 & 24 & 2.52 & 83 & 5.76 \\
\hline SDG 16 & 2 & 0.21 & 9 & 0.62 \\
\hline SDG 17 & 33 & 3.46 & 40 & 2.77 \\
\hline Total & 954 & 100.00 & 1442 & 100.00 \\
\hline \multicolumn{5}{|c|}{ Descriptive statistics measures } \\
\hline Mean & \multicolumn{2}{|c|}{56.00} & \multicolumn{2}{|c|}{84.82} \\
\hline Median & \multicolumn{2}{|c|}{44.00} & \multicolumn{2}{|c|}{43.00} \\
\hline $\begin{array}{c}\text { 1st } \\
\text { quartile }\end{array}$ & \multicolumn{2}{|c|}{24.00} & \multicolumn{2}{|c|}{28.00} \\
\hline $\begin{array}{c}\text { 3rd } \\
\text { quartile }\end{array}$ & \multicolumn{2}{|c|}{61.00} & \multicolumn{2}{|c|}{83.00} \\
\hline $\begin{array}{c}\text { Skewness } \\
\text { index }\end{array}$ & \multicolumn{2}{|c|}{2.97} & \multicolumn{2}{|c|}{2.74} \\
\hline $\begin{array}{l}\text { Standard } \\
\text { deviation }\end{array}$ & \multicolumn{2}{|c|}{72.04} & \multicolumn{2}{|c|}{108.18} \\
\hline
\end{tabular}

Then, we applied the "three pillars" concept of sustainable development $[8,29]$ to highlight the relations between the course content and certain dimensions of the SD. We referred also to the extended, four-dimensional approach (governance, economy, society and planet) proposed by Muff, Kapalka, Dyllick, [40]. In both cases, we examined the frequency of keywords in the goals most closely related to the discipline of economics and finance and sustainable economics. In the first case, the economic dimension was created by SDG 8, SDG 9, SDG 10 and SDG 12. A total of 507 keywords in the group of courses in economics and finance and 648 keywords in the group of sustainable economics were assigned to these four goals, which represented $53.1 \%$ in the first case and, respectively, $56.7 \%$ in the latter. After incorporating one more goal-SDG11, considered by researchers as an economic dimension - the number of keywords in the learning content significantly increased to 794 keywords which has resulted in $69.5 \%$ of all coded keywords for group of courses in sustainable economics (Table 4).

In total, the keywords relating to implementation of sustainable development goals through education were identified in 88 out of 123 courses classified in the economics and finance. Coursera courses accounted for about $50 \%$ of total number of courses with SDG-related issues offered on three analyzed platforms. The shares of edX and FutureLearn were $30 \%$ and $20 \%$, respectively. 
However, if we consider the relative ratio of the number of courses with references to SDG-related issues to the total number of courses provided on a given platform, we get a different picture. For FutureLearn, the ratio was the highest, with courses containing references to SDG accounting for $82 \%$ of all sampled courses offered on this platform, while for edX the ratio was $79 \%$, and for Coursera it was the lowest, amounting to $65 \%$.

Certainly, in all sustainable economics courses on all analyzed platforms, there was a content related to sustainability.

In view of the results obtained thus far, we have further focused on comparing the frequency of occurrence of analyzed keywords in both examined groups of courses. Our benchmark is the number of keywords in courses assigned to economics and finance (Figure 4).

Keywords identified in the MOOC syllabuses are characterized by different frequency of occurrence in both mentioned groups of courses. They represented about $60 \%$ of all identified expressions referring to sustainable development goals. For each of the keywords considered, it was important to relate them to the context of implementation of sustainable development goals in education. The leading keywords of MOOCs assigned to economics and finance indicate that the learning content of the courses is not limited to narrow concepts appropriate for economic goals only. They often present the wider approach covering environmental and social aspects. Through the use of various keywords, they bring a multidimensional or a holistic approach to the issues presented, even though there is still further progress to make. The conducted research shows that the most important topics are agri-food and sustainability issues among sampled MOOCs in economics and finance. However, the latter was more relevant for MOOCs related to sustainability economics. The global problem of climate change has been more often incorporated into economics and finance education than to specialist courses on sustainable economics. Similar results were obtained in case of education related to healthcare and gender concept. The concept of sustainable development was much more frequently invoked in the case of specialist MOOCs in the field of sustainable economics than in the courses classified to economics and finance discipline. Business, entrepreneurship and innovations as learning topics relatively frequently appeared in the courses of sustainable economics. The syllabuses also addressed issues related to environmental protection and biosphere, including the development of renewable energy, sustainable infrastructure, renewable resources and waste management or biodiversity and ecosystems. It seems, by contrast, that insufficient attention was paid to the problems of social inequalities and poverty (Figure 4).

The results of our study confirm that Education for Sustainable Development can and does support achieving sustainable development goals, through appropriate shaping of the curriculum. These findings go in line with the conclusions of the previous studies [41]. The study reveals that ESD can also contribute in particular (due to the rich sustainability-related course content) to the following goals: economic growth and decent work (SDG 8), health (SDG 3), sustainable consumption and production (SDG 12) and climate change (SDG 13), in addition to the SDG 4 referring entirely to education. These goals have direct references to the role of education (or scientific research) in the 2030 Agenda and the significance of education in achieving these goals is often underlined by UNESCO (2017b). Moreover, the obtained results in terms of identified keywords indicate that the course curricula concerning the sustainable development issues represent in many cases a multidimensional, transdisciplinary or holistic approach, despite being assigned to one specific research discipline [42-45]. They are not limited to economic topics, but also address social, environmental or other issues [46,47]. Trying to position ourselves among the previous researchers we found that, in case of some of previous studies on education for sustainable development goals, the data have been collected from literature review rather than from the course descriptions. Wu and Shen [48], based on academic literature in science and social sciences, have carried out research examining how the research topics match the research trends of teaching and curricula. In the second half of the first decade of the 2000s, the curriculum design mainly focused on the protection of the environment, whereas after 2008 curriculum design included increased role of ethics, sustainability, sustainable development, 
natural resources energy, ecology, promotion of citizenship. Their findings also indicated that, to achieve the earth's sustainability, higher education should involve integrative and interdisciplinary approach to ESD. Their findings are, in some aspects, in line with our observations, despite the use of a different research method.

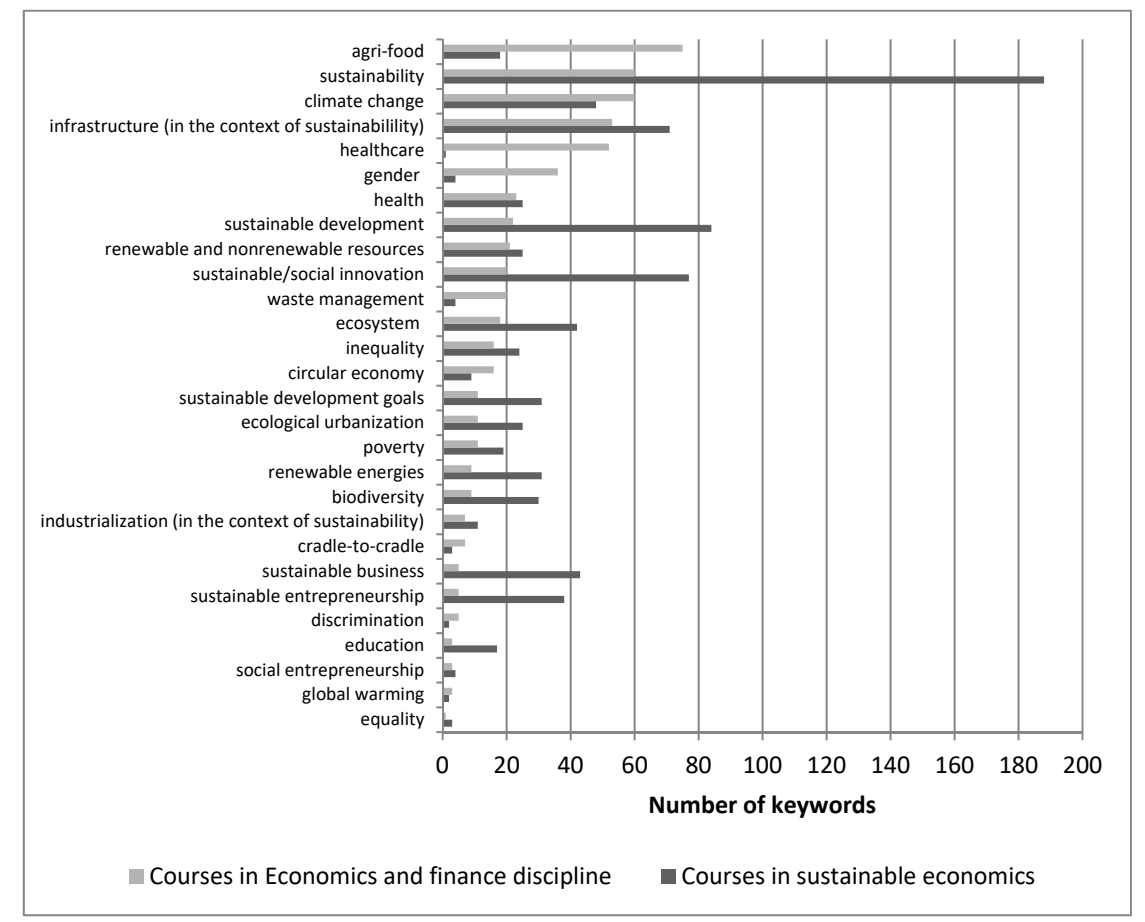

Figure 4. Core keywords included in both groups of courses. Source: own elaboration.

Interpreting our results in detail in the context of the research problem, it is not surprising to find that the most frequently addressed issues in the content of the courses in economics and finance are those related to SDG 8 ("Decent Work and Economic Growth"). It is also not unexpected that the second group of issues most often referred to in the analysed courses is the one related to SDG 9 ("Industry, Innovation and Infrastructure"), although it is noteworthy that a significantly lower number of references to SDG 9 than to SDG 8 was recorded. Somewhat surprising is the higher number of references to SDG 3 ("Good Health and Well-being") than SDG 12 ("Responsible Consumption and Production") in economics and finance course content. Additionally, it could be expected that poverty and hunger issues and inequalities concerns (SDG 1,2 and SDG 10) would be raised more frequently in the content of the courses than the actual research results indicate.

On the other hand, it is no surprise that issues not directly related to economics and finance, such as those referring to SGG 6 ("Clean Water and Sanitation"), SDG 14 ("Life below Water") or SDG 16 ("Peace, Justice and Strong Institutions") are addressed less frequently in the analysed course content. However, this does not mean that they should not be incorporated into the curricula to a greater extent. All these SDGs are interrelated, which means that it is impossible to fully achieve certain goals without knowing and paying attention to the others. Without communicating content on other SDGs, teaching about economic growth, entrepreneurship or innovations, even if these economic categories are viewed in the context of sustainability, can be a part of education about sustainable development but does not fully meet the requirements of education for sustainable development. Certainly, it may bring us closer to achieving individual goals (such as SDG 8 or SDG 9), as it allows learners to make more informed decisions in a given scope of issues, but it is unlikely to cause the desired change in attitudes and values or to ensure the acquisition of all the skills that are necessary to move societies towards sustainable development. 
In order to enable economics or finance students to become independent critical thinkers, who take responsible decisions and act in a sustainable manner in business environment, not being driven only by profits maximization, MOOCs have to make them aware about various aspects of sustainable development. Providing content on topics not directly related to economics, but addressing important social or environmental aspects, serves as a means to better inform students and sensitize them to these issues; this is because it is only due to the knowledge and understanding of these important issues that they will be able to take them into account when making future decisions related to work or private life. Only then can they become true sustainability change makers. Viewed from the interdisciplinary learning perspective, it seems that greater attention and better integration into the learning content is needed for such issues as, e.g., food security (related to SDG 2), gender discrimination (related to SDG 4), water distribution and sanitation (associated with SDG 6), global warming (within the scope of SDG 13), ocean pollutants (associated with SDG 14), deforestation (within the scope of SDG 15), or corruption an trade justice (related to SDG 16). Enhancing the knowledge on these issues is important not only for achieving specific goals related to them, but also other goals. Both social and environmental topics are addressed by many non-governmental organizations, but we cannot rely entirely on their educational efforts, especially since NGOs often have limited technical and organizational capacity to implement and fulfil their educational mission. Thus, strengthening education's contribution to the achievement of a new vision of sustainable development requires promoting these issues by integrating them into the learning content of MOOCs.

The courses on sustainable economics are dedicated to sustainability, so they take into account a broader range of social, economic and environmental issues related to sustainable development goals than economics and finance courses. However, also in their case, a greater emphasis on social issues such as gender equality (related to SDG 5) or corruption (associated with SDG 16) would be recommended.

The need for MOOCs' curricula to be interdisciplinary, more than before, is particularly evident in times of crises such as the current coronavirus pandemic, which poses a number of new challenges for the entire international community. At the same time, the role of MOOCs in education is growing in these turbulent times, due to the current heavy reliance on online communication and learning. They represent the learning format that seems to best meet the expectations of education for sustainable development in terms of providing inclusive, easily accessible and equitable education.

\section{Conclusions}

Education for Sustainable Development is a key instrument in transforming societies towards sustainability, supporting the achievement of Sustainable Development Goals. It is a centerpiece of the 2030 Agenda for Sustainable Development, explicitly formulated as a stand-alone Goal 4, one of 17 SDGs in the agenda, but strongly influencing the success of other goals. ESD faces serious challenges, as not all kinds of teaching support sustainable development. Education that focuses on economic growth alone may well also lead to an increase in unsustainable production and consumption. Thus, there is a need for strengthening education systems, which should provide inclusive, equitable quality education in a lifelong learning perspective. They should be focused on ensuring effective learning and relevant learning content leading to the acquisition of knowledge, skills and competencies, which are needed for promoting sustainable development. The quest for sustainable development requires monitoring the status and progress of implementation of Education for Sustainable Development.

In our research, we examined the integration of sustainable development goals into the learning content of MOOCs in the field of economics and finance. The analyzed MOOC courses included numerous references to the key challenging sustainability issues listed in the 2030 Agenda. In particular, the goals related to economic growth and decent work (SDG 8), innovation and infrastructure issues (SDG 9), health (SDG 3) and clean energy (SDG 7) were strongly reflected in MOOCs curricula. "Zero hunger" (SDG 2) and "Peace, Justice and Strong Institutions" (SDG 16) were least integrated goals into the MOOCs content in the field of economics and finance. The sustainability issues related 
to SDG 8 were reflected the most both in MOOCs in economics and finance and specialized MOOCs in sustainable economics. In case of the latter group of courses, a big number of references to quality education (SDG 4) and sustainable cities' and communities' issues (SDG 11) were also recorded. There were relatively few references in this set of courses to the goals "Life below Water" (SDG 14), "Peace, Justice and Strong Institutions" (SDG 16) and "Clean Water and Sanitation" (SDG 6).

MOOCs represent the learning format that seems to best meet the expectations of education for sustainable development in terms of providing inclusive, easily accessible and equitable education and lifelong learning opportunities. They have great potential in developing learners' knowledge, skills and values and attitudes required to lead productive lives in a sustainable manner, make informed decisions and face and resolve global challenges.

We found that education offered in the framework of MOOCs does actually support the achievement of sustainable development goals through appropriate shaping of the content of education, with many of SDG-related issues being reflected in the current MOOC curricula. However, in order to fully use the potential of MOOCs in providing education for sustainable development, further progress can be made in terms of including a broader spectrum of SDGs-related, interdisciplinary issues into the curricula. While, not surprisingly, the results of our research showed that the most frequently addressed issues in the content of the courses in economics and finance are those related to SDG 8 ("Decent Work and Economic Growth"), it must be remembered that all sustainable development goals are interrelated, so it is impossible to fully achieve certain goals without knowing and paying attention to the others. Without addressing such sensitive issues associated with other SDGs as for instance corruption, gender discrimination, food security or global warming, etc., teaching about economic growth or innovations would not meet all the requirements of education for sustainable development. In order to empower economics or finance students to become independent critical thinkers, who take responsible decisions and act in a sustainable manner in business environment, not being driven only by profits maximization, various important economic, social, environmental and other specific issues, related to all SDGs should be integrated into the MOOCs' learning content.

The main limitation of our research is the fact that it focuses only on one aspect of education for sustainable development-introducing certain content into course syllabuses-whereas the developments of the key competences needed for promoting sustainable developments require the creation of specific learning environment and using certain learning and teaching methods. Therefore, the further and broader research is needed to address the problem of designing, implementing and monitoring more action- and problem-oriented and learner-centered learning, both formal and informal, aimed at enabling a more sustainable society. Moreover, our study is limited to the MOOCs chosen from three selected platforms and representing the field of economics and finance only. It would be valuable to include in further research more platforms and courses, focusing on other aspects of sustainable development (social, environmental, technological, etc.).

Despite the limitations, the contributions and implications of the study are meaningful. It supports educators' efforts in identifying and mainstreaming challenging issues within the processes of curriculum renewal and development as an important step towards education for sustainable development goals. It can serve as a reference material for curriculum developers and specialists, development experts, policy makers, teacher trainers, supervisors, principals, teachers, researchers and other stakeholders involved in educational processes. The study provides insights in the MOOCs offered in finance and economics on leading online platforms and points the way to further research that is needed to investigate and understand the learning offered at different levels and the means of better integrating MOOCs into more learner-centered active teaching and learning for sustainable development. It recognises how important it is to empower learners to contribute to sustainable development, through providing them with integrative learning and interdisciplinary understanding, enabling them to cope with present and upcoming challenges in a sustainable manner.

Author Contributions: This paper is a result of the full collaboration of the authors. The contribution of the co-authors is equal. Conceptualization, A.H. and B.P.; Methodology, A.H. and B.P. Formal analysis and 
investigation, A.H. and B.P.; writing the Literature Review, Introduction and Conclusions, A.H. and B.P. All authors have read and agreed to the published version of the manuscript.

Funding: This publication is financed with the subsidy granted to the Cracow University of Economics.

Acknowledgments: We thank the reviewers for their constructive comments.

Conflicts of Interest: The authors declare no conflict of interest.

\section{References}

1. UNESCO. Education for Sustainable Development Goals; Learning Objectives; The United Nations Educational, Scientific and Cultural Organization, UNESCO Publishing: Paris, France, 2017.

2. Disterheft, A.; Caeiro, S.; Azeiteiro, U.M.; Leal Filho, W. Sustainability Science and Education for Sustainable Development in Universities: A Way for Transition. In Sustainability Assessment Tools in Higher Education Institutions: Mapping Trends and Good Practices Around the World; Leal Filho, W., Caeiro, S., Azeiteiro, U.M., Jabbour, C., Eds.; Springer: Cham, Switzerland, 2013; pp. 3-27. [CrossRef]

3. Egana del Sol, P.A. Education for sustainable development: Strategies and key issues. In Quality Education; Leal Filho, W., Azul, A.M., Brandli, L., Gökcin Özuyar, P., Wall, T., Eds.; Springer: Cham, Switzerland, 2019; pp. 1-15. [CrossRef]

4. Shulla, K.; Leal Filho, W.; Sommer, J.H.; Lardjane, S.; Borgemeister, C. Sustainable development education in the context of the 2030 Agenda for sustainable development. Int. J. Sustain. Dev. World Ecol. 2020, 27, 458-468. [CrossRef]

5. United Nations World Commission on Environment and Development. Our Common Future. 1987. Available online: https://sustainabledevelopment.un.org/content/documents/5987our-common-future.pdf (accessed on 20 July 2020).

6. International Union for Conservation of Nature and Natural Resources; United Nations Environmental Programme; World Wildlife Fund Caring for the Earth. A Strategy for Sustainable Living. 1991. Available online: https://portals.iucn.org/library/efiles/documents/cfe-003.pdf (accessed on 20 July 2020).

7. Saviano, M.; Di Nauta, P.; Montella, M.M.; Sciarelli, F. The Cultural Value of Protected Areas as Models of Sustainable Development. Sustainability 2018, 10, 1567. [CrossRef]

8. Klarin, T. The Concept of Sustainable Development: From its Beginning to the Contemporary Issues. Zagreb Int. Rev. Econ. Bus. 2018, 21, 67-94. [CrossRef]

9. Purvis, B.; Mao, Y.; Robinson, D. Three pillars of sustainability: In search of conceptual origins. Sustain. Sci. 2018. [CrossRef]

10. United Nations Conference on Environment and Development. Rio Declaration on Environment and Development 1992. Available online: http://www.un.org/documents/ga/conf151/aconf15126-1annex1.htm (accessed on 20 August 2020).

11. Lohrmann, C. Online learning_Do MOOCs Contribute to the Goals of Agenda 21: "Education for Sustainable Development"? In Sustainability in a Digital World; New Opportunities Through New Technologies, Series: CSR, Sustainability, Ethics \& Governance; Osburg, T., Lohrmann, C., Eds.; Springer: Cham, Switzerland, 2017. [CrossRef]

12. UNESCO. Rethinking Education. Towards a Global Common Good; The United Nations Educational, Scientific and Cultural Organization, UNESCO Publishing: Paris, France, 2015.

13. Vare, P.; Scott, W. Learning for a change exploring the relationship between education and sustainable development. J. Educ. Sustain. Dev. 2007, 1, 191-198. [CrossRef]

14. United Nations. Resolution adopted by the General Assembly on 25 September 2015. Transforming Our World: The 2030 Agenda for Sustainable Development. Available online: https://www.un.org/ga/search/view_ doc.asp?symbol=A/RES/70/1\&Lang=E (accessed on 24 July 2020).

15. Leal Filho, W.; Tripathi, S.K.; Andrade Guerra, J.B.S.O.D.; Giné-Garriga, R.; Orlovic Lovren, V.; Willats, J. Using the sustainable development goals towards a better understanding of sustainability challenges. Int. J. Sustain. Dev. World Ecol. 2019, 26, 179-190. [CrossRef]

16. Sachs, J.D.; Schmidt-Traub, G.; Mazzucato, M.; Messner, D.; Nakicenovic, N.; Rockström, J. Six Transformations to achieve the Sustainable Development Goals. Nat. Sustain. 2019, 2, 805-814. [CrossRef] 
17. UNESCO. Unpacking Sustainable Development Goal 4. Education 2030: Guide; The United Nations Educational, Scientific and Cultural Organization, UNESCO Publishing: Paris, France, 2017.

18. Johnston, T.C. What makes a MOOC? Massive Open Online Courses (MOOCs) Compared to Mainstream Online University Courses. J. Learn. High. Educ. 2014, 10, 17-23.

19. Mazoue, J. The MOOC Model: Challenging Traditional Education, EDUCAUSE. 2013. Available online: https://er.educause.edu/articles/2013/1/the-mooc-model-challenging-traditional-education (accessed on 20 July 2020).

20. Cha, H.; So, H.-J. Integration of Formal, Non-formal and Informal Learning Through MOOCs. In Radical Solutions and Open Science, An Open Approach to Boost Higher Education; Burgos, D., Ed.; Springer: Singapore, 2010; pp. 135-158. [CrossRef]

21. Islam, M.F.; Akter, T.; Knezevic, R. The Role of MOOCs in Achieving the Sustainable Development Goal Four. In Proceedings of the Western Balkans Information and Media Literacy Conference, Bihac, Bosnia and Herzegovina, 20-21 June 2019; Available online: https://www.researchgate.net/publication/334112867_THE_ROLE_OF_MOOCs_IN_ACHIEVING_

THE_SUSTAINABLE_DEVELOPMENT_GOAL_FOUR/link/5d1786c692851cf44056eeb4/download (accessed on 20 July 2020).

22. Sanchez-Gordon, S.; Luján-Mora, S. MOOCs gone wild. In Proceedings of the 8th International Technology, Education and Development Conference (INTED 2014), Valencia, Spain, 10-12 March 2014; pp. 1449-1458.

23. Bordoloi, R. Transforming and empowering higher education through Open and Distance Learning in India. Asian Assoc. Open Univ. J. 2018, 13, 24-36. [CrossRef]

24. Trajković, S.; Prokić-Cvetković, R.; Popović, O. Massive Open Online Courses (MOOC) and Its Possibilities as Instrument of Formal, Nonformal, Informal and Lifelong Learning. In Virtual Learning; IntechOpen: Rijeka, Croatia, 2016; Available online: https://www.intechopen.com/books/virtual-learning/massive-openonline-courses-mooc-and-its-possibilities-as-instrument-of-formal-nonformal-informal-an (accessed on 24 August 2020).

25. Coursera. Impact Revealed-Learners Outcome in Open Online Courses. 2014. Available online: https://d396qusza40orc.cloudfront.net/learninghubs/LOS_final\%209-21-.pdf (accessed on 20 July 2020).

26. Zawacki-Richter, O.; Bozkurt, A.; Alturki, U.; Aldraiweesh, A. What Research Says About MOOCs-An Explorative Content Analysis. Int. Rev. Res. Open Distrib. Learn. 2018, 19, 242-259. [CrossRef]

27. Porter, S. The economics of MOOCs: A sustainable future? Bottom Line 2015, 28, 52-62. [CrossRef]

28. Bird, E.; Lutz, R.; Warwick, C. Media as Partners in Education for Sustainable Development: A Training and Resource Kit; UNESCO Series on Journalism Education; UNESCO: Paris, France, 2008; Volume 5.

29. Bergman, Z.; Bergman, M.M.; Fernandes, K.; Grossrieder, D.; Schneider, L. The Contribution of UNESCO Chairs toward Achieving the UN Sustainable Development Goals. Sustainability 2018, 10, 4471. [CrossRef]

30. Class Central. Providers. 2020. Available online: https://www.classcentral.com/providers (accessed on 10 August 2020).

31. About Cousera 2020. Available online: https://about.coursera.org (accessed on 10 August 2020).

32. About edX 2020. Available online: https://www.edx.org/about-us (accessed on 10 August 2020).

33. About FutureLearn 2020. Available online: https://www.futurelearn.com/partners (accessed on 10 August 2020).

34. Gamage, D.; Perera, I.; Fernando, S. Evaluating effectiveness of MOOCs using empirical tolls: Learning perspective. In Proceedings of the 10th International Technology Education and Development Conference, Valencia, Spain, 7-9 March 2016; Available online: https: //www.researchgate.net/publication/298417324_Evaluating_effectiveness_of_MOOCs_using_Empirical_ ToolsLearners_perspective/link/56e9509008ae47bc651c6a9a/download (accessed on 5 October 2020).

35. Ruipérez-Valiente, J.A.; Jenner, M.; Staubitz, T.; Li, X.; Rohloff, T.; Halawa, S.; Turro, C.; Cheng, Y.; Zhang, J.; Despujol, I.; et al. Macro MOOC Learning Analytics: Exploring Trends Across Global and Regional Providers. In Proceedings of the Learning Analytics \& Knowledge Conference 2020, Frankfurt, Germany, 23-27 March 2020; Available online: https://edarxiv.org/9ghfc/ (accessed on 5 October 2020).

36. Ruipérez-Valiente, J.A.; Halawa, S.; Slama, R.; Reich, J. Using multi-platform learning analitycs to compare regional and global MOOC learning in the Arab world. Comput. Educ. 2020, 146, 103776. [CrossRef]

37. Coursera. Available online: https://www.coursera.org/ (accessed on 24 July 2020).

38. edX. Available online: https://www.edx.org/ (accessed on 31 July 2020). 
39. FutureLearn. Available online: https://www.futurelearn.com/ (accessed on 5 August 2020).

40. Muff, K.; Kapalka, A.; Dyllick, T. Moving the world into a safes pace-The GRAPFRAME methodology. Int. J. Manag. Educ. 2018, 16, 349-369.

41. Zhan, Z.; Fong, P.S.; Mei, H.; Chang, X.; Liang, T.; Ma, Z. Sustainability Education in Massive Open Online Courses: A Content Analysis Approach. Sustainability 2015, 7, 2274-2300. [CrossRef]

42. Stables, A.; Scott, W. The Quest for Holism in Education for Stustainable Development. Environ. Educ. Res. 2002, 8, 53-60. [CrossRef]

43. Ashford, N.A. Major Challenges to Engineering Education for Sustainable Development: What Has to Change to Make It Creative. Effective, and Acceptable to the Established Disciplines. Int. J. Sustain. High. Educ. 2004, 4, 239-250. [CrossRef]

44. Annan-Diab, F.; Molinari, C. Interdisciplinarity: Practical approach to advancing education for sustainability and for the Sustainable Development Goals. Int. J. Manag. Educ. 2017, 15 Pt B, 73-83. [CrossRef]

45. Sachs, J.D. The Age of Sustainable Development. Project Syndicate. The World's Opinion Page. 2014. Available online: http://www.project-syndicate.org/print/jeffrey-d--sachs-proposes-a-new-curriculum-for-anew-era (accessed on 24 July 2020).

46. Angiel, J.; Angiel, P.J. Perception of River Value in Education for Sustainable Development (The Vistula River, Poland). Sustain. Dev. 2015, 23, 188-201. [CrossRef]

47. Webster, K. Missing the wood for the trees: Systematic defects and the future of education for sustainable development. Curric. J. 2013, 24, 295-315. [CrossRef]

48. Wu, Y.-C.J.; Shen, J.-P. Higher education for sustainable development: A systematic review. Int. J. Sustain. High. Educ. 2015, 17, 633-651. [CrossRef]

Publisher's Note: MDPI stays neutral with regard to jurisdictional claims in published maps and institutional affiliations. 